Biochimica et Biophysica Acta

Elsevier Publishing Company, Amsterdam - Printed in The Netherlands

BBA 96996

\title{
PROTEOLYTIC ACTIVITY OF PARTLY PURIFIED RIBONUCLEASE INHIBITOR FROM RAT LIVER
}

\author{
A. J. M. BERNS, A. ZWEERS, A. A. M. GRIBNAU AND H. BLOEMENDAL.* \\ Department of Biochemistry, University of Nijmegen, Nijmegen (The Netherlands) \\ (Received May Igth, I97 I)
}

SUMMARY

Increasing interest has been focused on ribonuclease inhibitor from rat liver as protecting agent in studies on polyribosomes. Most investigators use either the crude I00 $000 \times g$ supernatant or a preparation partly purified on DEAE-Sephadex. Whereas partially purified material protects the integrity of the polysomes, it contains a component that interferes with peptide formation. The interfering activity is of proteolytic nature and can be removed by gel filtration on Sephadex G-roo.

Evidence is provided that at least part of the enzymic activity has to be ascribed to a potent leucine aminopeptidase.

Recently we reported the isolation and purification of a polysome stabilizing factor from rat liver ${ }^{1,2}$ identical with the ribonuclease inhibitor, first described by RoTH $^{3}$. We use this factor as protecting agent in the isolation procedure for intact polysomes, ribosomal subunits and the preparation of run-off ribosomes, which is performed under conditions of amino acid incorporation. For the isolation of intact polysomes from leukemic spleen the presence of the factor was a prerequisite ${ }^{4}$, and when ribosomal subunits from bovine eye lens tissue had to be prepared, we frequently observed that an almost complete degradation of the $40-\mathrm{S}$ subunit occurred when the stabilizing factor was omitted.

In various other laboratories, too, the crude roo $000 \times g$ supernatant or the inhibitor partly purified on DEAE-cellulose according to SHoRTMAN ${ }^{5}$ has been used to obtain intact polysomes from different sources $^{8-8}$.

It may also be advantageous to use the ribonuclease inhibitor in amino acid incorporation experiments. However, while studying protein biosynthesis in the eye lens system, we observed that on the one hand the inhibitor partly purified on DEAESephadex prevented polyribosomes from degradation, but on the other hand the amino acid incorporation was diminished. We found that further purification of the DEAE-Sephadex material on Sephadex G-Ioo (Fig. $x$ ) was necessary to obtain optimal incorporation of amino acid (Fig. 2).

The inhibitory effect of both the DEAE-Sephadex material and of Peak I from Sephadex G-IOo is evident. During the first Io min of incubation there was only a slight difference in effect on amino acid incorporation of either of the fractions tested. This may mean that the accessibility of the newly formed peptide chains

\footnotetext{
" To whom requests for reprints should be addressed.
}

Biochim. Biophys. Acia, 247 (197I) 62-65 


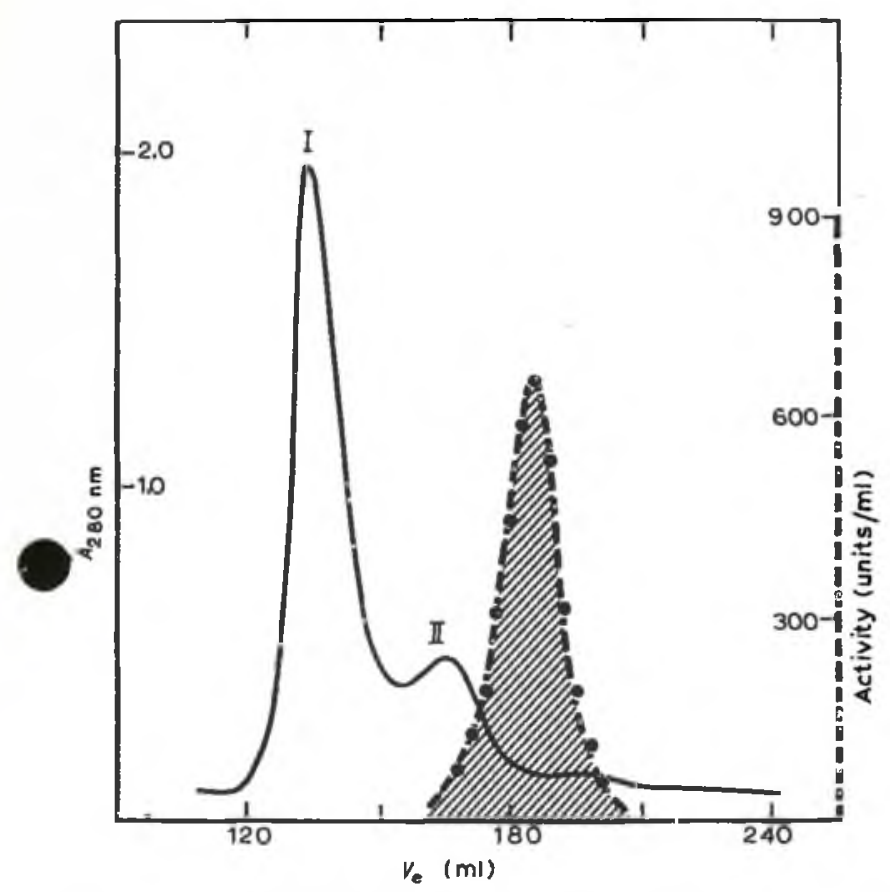

Fig. I. Gel filtration of the partly purified ribonuclease inhibitor on Sephadex G-Ioo. inhibitor activity.

is involved in this phenomenon. If this is true proteolytic activity might explain the inhibitory effect on amino acid incorporation. To test this assumption we incubated the different ribonuclease inhibitor fractions with ${ }^{\mathrm{I} 4} \mathrm{C}$-labeled hemoglobin, prepared according to LOcKARD et al. ${ }^{9}$ by incubation for $2 \mathrm{~h}$ of a reticulocyte lysate system with $\left[{ }^{14} \mathrm{C}\right]$ leucine. After removal of the ribosomes the supernatant was passed through a Sephadex G-25 column and the void volume was designated as radioactive hemoglobin. The results are listed in Table I. From Fig. 2 it can be concluded that the gel filtration step removes the "inhibitory" activity on amino acid incorporation whereas Table I shows that this activity is due to some kind of proteolysis, as the hot tri-

\section{TABLE I}

DEGRADATION OF RADIOACTIVE HEMOGLOBIN AFTER INCUBATION IN THE PRESENCE OF CERTAIN RIBONUCLEASE INHIBITOR FRACTIONS

The undegraded hemoglobin used in the incubation experiment corresponded with 8500 disint./ min. Incubation was for $2 \mathrm{~h}$. The buffer consisted of $0.05 \mathrm{M}$ Tris- $\mathrm{HCl}(\mathrm{pH} 7.6$ ), $0.07 \mathrm{M} \mathrm{KCl}$, $0.005 \mathrm{M}$ magnesium acetate and $0.001 \mathrm{M}$ dithiothreitol.

\begin{tabular}{ll}
\hline Addition & Radioactivity (disind./min) \\
\hline Buffer only & 8300 \\
DEAE-Sephadex material (700 $\mu \mathrm{g}$ protein) & 5300 \\
Sephadex G-roo Fraction I $(525 \mu \mathrm{g})$ & 5500 \\
Sephadex G-roo inhibitor (1 $5 \mu \mathrm{g})$ & 8200 \\
Serum albumin. (control for self absorption) $(700 \mu \mathrm{g})$ & 8300 \\
\hline
\end{tabular}

\footnotetext{
* 75 units.
} 


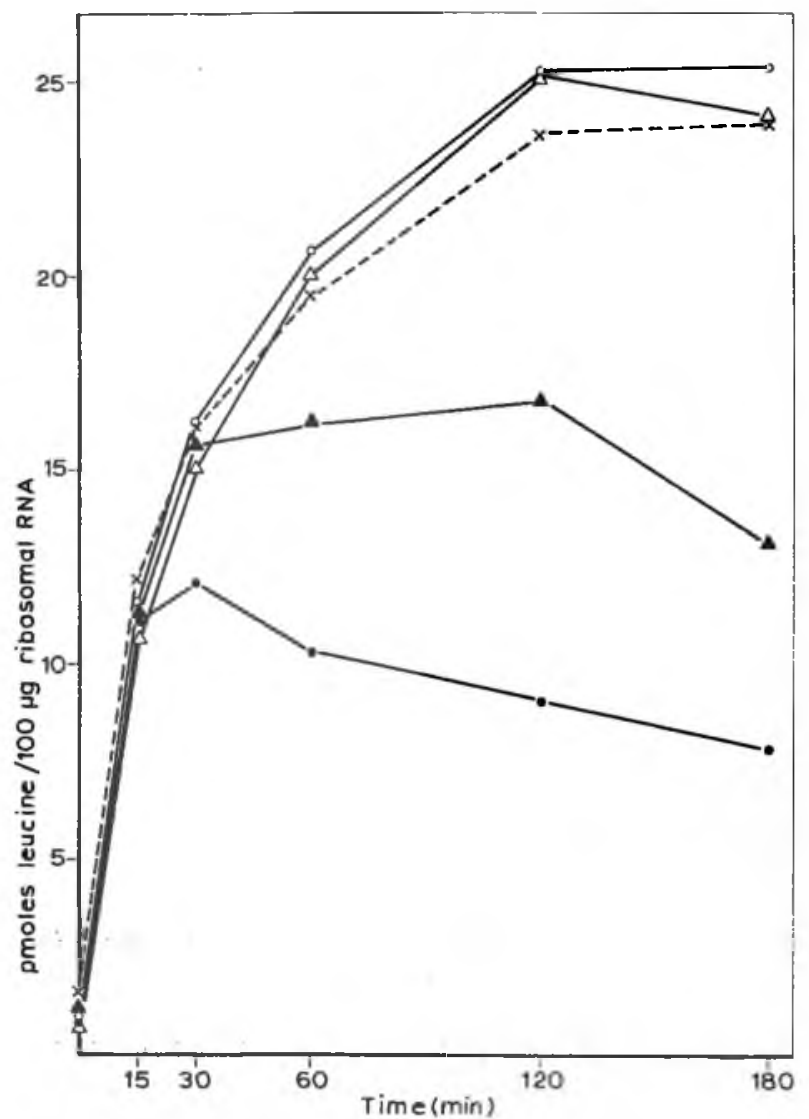

Fig. 2. $\left[{ }^{14} \mathrm{C}\right]$ Leucine incorporation activity of calf lens polyribosomes in the presence of different protein fractions. Calf lens polyribosomes ${ }^{11}$ (roo $\mu \mathrm{g}$ RNA) were incubated during different time intervals with calf lens supernatant ( $2 \mathrm{mg}$ of protein). The incubation mixtures contained 1.25 $\mu$ moles phosphoenolpyruvate, $0.125 \mu$ mole ATP, $0.063 \mu$ mole GTP, $0.69 \mathrm{mg}$ 2-mercaptoethanol, I 2.5 $\mu$ g pyruvate kinase (EC 2.7.2.40), ro $\mu$ moles $\mathrm{DL}\left[\mathrm{I}-{ }^{14} \mathrm{C}\right]$ leucine (specific activity $34 \mathrm{mC} / \mathrm{mmole}$ ) a mixture of unlabeled amino acids (excluding leucine) ro nmoles per amino acid. All components were dissolved in Medium B, containing $0.05 \mathrm{M}$ Tris- $\mathrm{HCl}$ buffer ( $\mathrm{pH} 7.6$ ), $0.008 \mathrm{M} \mathrm{MgCl}_{2}$ and $0.025 \mathrm{M} \mathrm{KCl}$. The final volume was $0.25 \mathrm{ml}$. Incubation was performed for $45 \mathrm{~min}$ at $37^{\circ}$. At zero time $25 \mu$ l of the following fractions were added: $\times---\times$, buffer, $\bigcirc-O$, Sephadex G-1oo ribonuclease inhibitor fraction (II $\mu \mathrm{g}$ of protein, Io2 units); $\boldsymbol{\Delta}-\boldsymbol{\Delta}$, Sephadex G-Ioo first protein peak ( $328 \mu \mathrm{g}$ of protein); $\Delta-\Delta$, Sephadex G-Ioo second protein peak (328 $\mu \mathrm{g}$ of protein);

DEAE-Sephadex ribonuclease inhibitor fraction (4I0 $\mu \mathrm{g}$ of protein, Io2 units). After different time the reaction was stopped by the addition of trichloroacetic acid. With reticulocyte polyribosomes similar results were obtained.

chloroacetic acid-precipitable radioactive material diminished about $30 \%$ after incubation with crude DEAE-Sephadex inhibitor or Sephadex G-Ioo Fraction I. In gel filtration on Sephadex G-5o the degradation products of hemoglobin emerged in the region of free amino acids.

We provide evidence that a potent leucine amino peptidase is, at least partly, responsible for the proteolytic activity. According to BERNT AND BERGMEY$\mathbf{E R}^{10}$, L-leucyl- $\beta$-naphthylamine hydrochloride is a highly specific substrate for this enzymic activity. I mg of the DEAE-Sephadex material contains as much as 0.3 
I.U. of the enzyme. The proteolytic activity that originates from the soluble enzyme fraction also attacks growing peptide chains. This was demonstrated by replacing the radioactive hemoglobin by ribosome-bound peptides.

These findings have to be kept in mind during studies on protein synthesis in a cell-free system in which rat liver cell sap is used. In particular, it will be difficult to draw unequivocal conclusions concerning the terminal $\mathrm{NH}_{2}$ of newly formed polypeptides in the homologous system from rat liver in vitro.

\section{ACKNOWLEDGEMENTS}

The present investigation was carried out partly under the auspices of the Netherlands Foundation for Chemical Research (S.O,N.), and with financial aid from the Netherlands Organization for the Advancement of Pure Research (Z.W.O.).

\section{REFERENCES}

i A. A. M. Gribnau, J. G. G. Schoenmakers and H. Bloemendal, Arch. Biochem. Biophys., I30 (I969) 48 .

2 A. A. M. Gribnau, J. G. G. Schoenmakers, M. van Kratikamp and H. Blogmendal, Biochem. Biophys. Res. Commun., $3^{8}$ (1970) 1064.

3 J. S. Roth, Biochim. Biophys. Acta, 2I (I956) 34.

4 J. Th. M. Burghouts, A. L. H. Stols and H. Bloemendal, Biochem. J., II9 (1970) 749.

5 K. Shortman, Biochim. Biophys. Acta, 55 (I962) 88.

$6 \mathrm{H}$. Sugano, I. Watanabe and K. Ogata, Biochem. $J$., 6I (1967) $77^{8}$.

7 T. Moriyama, T Umeda, S. Nakashima, H. Oura and K. Tsukada, Biochem. J., 66 (1969) I5I.

8 M. Takagi and K. Ogata, Biochem. Biophys. Res. Commun., 42 (I97I) I25.

9 R. E. Lockard and J. B. Lingrel, Biochem. Biophys. Res. Commun., 37 (I969) 204.

io E. Bernt and H. U. Bergmeyer, Methods of Enzymatic Analysis, Academic Press, New York, 1963, p. 833.

11 H. Blofmendal, J. G. G. Schoenmakers, A. Zwiers, R. Matze and E. L. Benedecti, Biochim. Biophys. Acta, 123 (1966) 217. 